\title{
ACETYLCHOLINE AND THE PULMONARY CIRCULATION IN MITRAL VALVULAR DISEASE
}

\author{
BY \\ BROR SÖDERHOLM AND LARS WERKÖ* \\ From the Department of Clinical Physiology and the First Medical Service, Sahlgrenska Sjukhuset, University of
Göteborg, Sweden \\ Received March 17, 1958
}

Pulmonary hypertension can be due either to transmission of increased left atrial pressure (passive pulmonary hypertension), to increased pulmonary blood flow (hyperkinetic pulmonary hypertension), or to increased pulmonary vascular resistance caused by increase in vascular tone (active pulmonary hypertension) or by anatomical narrowing of the vascular bed. In mitral stenosis most of the patients have passive pulmonary hypertension but in 10-20 per cent of those studied by means of heart catheterization the pulmonary arterial pressure is increased out of proportion to the height of the left atrial pressure with a low cardiac output. This has been interpreted as due to active constriction of the small pulmonary arteries in an effort to protect the capillaries from the high pressure (protective pulmonary hypertension).

The rapid injection of 1-2 mg. of acetylcholine in the pulmonary artery of patients with a variety of heart disorders, notably mitral stenosis with pulmonary hypertension, sometimes lowered the pulmonary artery pressure, indicating the functional nature of the increased pulmonary arterial pressure (Harris 1957).

Fritts et al. (1958) have demonstrated that the increase of pulmonary arterial pressure that is caused by breathing a gas mixture with low oxygen content can be abolished by a simultaneous infusion of acetylcholine in a dose sufficiently small to be destroyed before it reaches the general circulation: in this way the influence of acetylcholine on the peripheral vascular bed is avoided. In order to investigate the nature of the pulmonary hypertension in mitral stenosis, Wood et al. (1957) used acetylcholine to differentiate between functional and anatomical changes. They gave $1 \cdot 0$ $2.0 \mathrm{mg}$. acetylcholine rapidly in the pulmonary artery to nine cases of mitral stenosis with active pulmonary hypertension and found a decrease of pressure with unchanged cardiac output: at the same time the left atrial pressure increased somewhat. This was used as evidence that the pulmonary hypertension was protective and at least initially of a functional nature.

The present study was undertaken in view of the importance of the nature of pulmonary hypertension in those cases of mitral stenosis referred to operation. To test the validity of the theory of the protective nature of the increased pressure, the influence of an infusion of acetylcholine on pulmonary pressures and blood flow was studied both at rest and during exercise in a way that insured steady state conditions.

\section{Methods}

The patients were studied in the morning, recumbent and in the post-absorptive state. The pulmonary artery was catheterized according to Cournand. A double lumen catheter was always used. A polyethylene catheter was placed in the brachial artery. After these procedures were completed the patient rested for approximately 30 minutes. Pressures were then recorded in the wedge position, in the pulmonary artery, the right ventricle and auricle, and the brachial artery. Cardiac output was determined according to the

* Aided by a grant from the National Foundation against Tuberculosis and other chronic diseases, Stockholm. 
direct Fick principle, with simultaneous collection of expired air and sampling of pulmonary arterial and brachial arterial blood. The oxygen content in the air was determined on a Haldane apparatus and in the blood with a Beckman photometer.

After the basal observations had been made acetylcholine was infused in the pulmonary artery under continuous recording of blood pressures. The dose was increased until some effect was noted on the pulmonary arterial pressure (3 to $14.5 \mathrm{mg}$. $/ \mathrm{min}$.). During constant infusion of this dose the cardiac output was again determined and pressures registered, after which the infusion was interrupted.

After 10-15 minutes of rest, still in the recumbent position, an exercise test was done using an electrically braked bicycle. The patient usually performed about $100 \mathrm{~kg} . / \mathrm{min}$. When a steady state had been reached (after 5-7 min.) pressures were recorded and the cardiac output determined. With the patient continuing the exercise, the acetylcholine infusion was again started using the same amount of acetylcholine as the highest previous dose. The cardiac output was then again determined and blood pressures registered. After that, the exercise was interrupted and the infusion stopped. In some patients the study was ended with another cardiac output determination.

Pressures were recorded using an Elema strain gauge, and mean pressure was obtained with electrical integration. In three patients the carbon dioxide partial pressure was determined in the arterial blood, using a modified Astrup technique.*

The physical characteristics of the patients are listed in Table I. Each had been referred to the hospital for evaluation of operability. Subject $18 / 57$ was found to have pure mitral regurgitation at operation.

TABLE I

Clinical Data of 13 Patients with Mitral Valvular Disease

\begin{tabular}{|c|c|c|c|c|c|c|c|}
\hline Case No. & Sex & Age & $\begin{array}{c}\mathrm{BSA} \\
\mathrm{m}^{2}\end{array}$ & $\begin{array}{l}\text { Heart volume } \\
\mathrm{m}^{2} \text { BSA }\end{array}$ & Group* & \multicolumn{2}{|l|}{ Diagnosis } \\
\hline $\begin{array}{l}18 / 57 \\
20 / 57 \\
37 / 57 \\
41 / 57 \\
42 / 57 \\
46 / 57 \\
47 / 57 \\
50 / 57 \\
56 / 57 \\
58 / 57 \\
4 / 58 \\
6 / 58 \\
8 / 58\end{array}$ & $\begin{array}{l}\mathrm{F} \\
\mathrm{F} \\
\mathrm{M} \\
\mathrm{F} \\
\mathrm{F} \\
\mathrm{F} \\
\mathrm{F} \\
\mathrm{F} \\
\mathrm{M} \\
\mathrm{F} \\
\mathrm{F} \\
\mathrm{M} \\
\mathrm{F}\end{array}$ & $\begin{array}{l}36 \\
46 \\
46 \\
48 \\
50 \\
54 \\
43 \\
45 \\
46 \\
37 \\
41 \\
44 \\
55\end{array}$ & $\begin{array}{l}1.74 \\
1.71 \\
2.06 \\
1.54 \\
1.75 \\
1.75 \\
1.67 \\
1.77 \\
1.62 \\
1.86 \\
1.75 \\
1.59 \\
1.59\end{array}$ & $\begin{array}{l}930 \\
520 \\
800 \\
780 \\
650 \\
500 \\
810 \\
570 \\
690 \\
490 \\
710 \\
500 \\
610\end{array}$ & $\begin{array}{r}\text { III } \\
\text { II } \\
\text { II } \\
\text { II } \\
\text { II } \\
\text { II } \\
\text { II } \\
\text { II } \\
\text { III } \\
\text { II } \\
\text { III } \\
\text { II } \\
\text { II }\end{array}$ & $\begin{array}{l}\text { MI } \\
\text { MI +MS } \\
\text { MS+AS } \\
\text { MS } \\
\text { MS } \\
\text { MS } \\
\text { MS+AS } \\
\text { MI +MS } \\
\text { MS+Spondylarthritis } \\
\text { MS+MI } \\
\text { MS } \\
\text { MS } \\
\text { MS }\end{array}$ & $\begin{array}{l}\text { AF } \\
\text { AF } \\
\text { SN } \\
\text { AF } \\
\text { SN } \\
\text { AF } \\
\text { AF } \\
\text { SN } \\
\text { SN } \\
\text { AF } \\
\text { SN } \\
\text { AF }\end{array}$ \\
\hline $\begin{array}{l}\mathrm{MS}=\mathrm{M} \\
\mathrm{MI}=\mathrm{M}\end{array}$ & & & & . & & $\begin{array}{l}\text { Sinus rhythm. } \\
\text { Atrial fibrillation. }\end{array}$ & \\
\hline
\end{tabular}

\section{RESULTS}

Table II gives the figures for blood flow, oxygen saturation, and blood pressures at rest and during infusion of acetylcholine in varying amounts. The cardiac output stayed the same or rose somewhat, the oxygen saturation and the pressure in the pulmonary artery decreased, usually with no change of heart rate or brachial arterial pressure.

Table III contains the same data during exercise before and during the infusion of acetylcholine. The cardiac output varied only slightly with no change in brachial arterial pressure, but with a decrease in arterial oxygen saturation and pulmonary arterial pressures.

* Ass. Prof. S. Stenhagen helped us with these determinations. 
TABLE II

Respiratory and CaRdiac Data before, duRING, aNd after a Constant Infusion of ACETylCholine at Rest

\begin{tabular}{|c|c|c|c|c|c|c|c|c|c|c|}
\hline Case No. & & Heart rate & $\mathrm{V}_{\mathrm{O}_{2}}$ & $\mathrm{~A}-\mathrm{V}_{\mathrm{O}_{2}}$ & $\mathrm{CO}$ & $\mathrm{SaO}_{2}$ & $\overline{\mathrm{P}}_{\mathrm{PA}}$ & $\overline{\mathrm{P}}_{\mathrm{BA}}$ & A. chol. dose* & PCV \\
\hline $18 / 57$ & $\begin{array}{l}\text { B } \\
\text { D } \\
\text { D } \\
\end{array}$ & $\begin{array}{l}116 \\
115 \\
100\end{array}$ & $\begin{array}{l}0 \cdot 239 \\
0 \cdot 217 \\
0 \cdot 230\end{array}$ & $\begin{array}{l}81 \\
73 \\
64\end{array}$ & $\begin{array}{l}3.0 \\
3.0 \\
3.6\end{array}$ & $\begin{array}{l}96 \cdot 7 \\
98 \cdot 0 \\
94 \cdot 4\end{array}$ & $\begin{array}{l}80 \\
46 \\
47\end{array}$ & $\begin{array}{l}116 \\
111 \\
109\end{array}$ & $\begin{array}{l}\overline{11.5} \\
14.5\end{array}$ & 17 \\
\hline $20 / 57$ & $\begin{array}{l}\text { B } \\
\text { D } \\
\text { D } \\
\text { D }\end{array}$ & $\begin{array}{l}110 \\
118 \\
110 \\
110\end{array}$ & $\begin{array}{c}0.240 \\
\overline{0} .231 \\
-\end{array}$ & $\frac{53}{56}$ & $\begin{array}{l}\frac{4 \cdot 5}{4 \cdot 1} \\
-\end{array}$ & $\begin{array}{l}97 \cdot 0 \\
94 \cdot 2 \\
94 \cdot 3 \\
92 \cdot 9\end{array}$ & $\begin{array}{l}29 \\
31 \\
29 \\
28\end{array}$ & $\begin{array}{l}123 \\
128 \\
130 \\
127\end{array}$ & $\begin{array}{l}\overline{6 \cdot 5} \\
12 \\
14 \cdot 5\end{array}$ & \\
\hline $37 / 57$ & $\begin{array}{l}\text { B } \\
\text { D } \\
\text { D } \\
\text { A }\end{array}$ & $\begin{array}{l}80 \\
78 \\
74 \\
70\end{array}$ & $\begin{array}{c}0.313 \\
- \\
-\end{array}$ & $\frac{48}{42}$ & $\begin{array}{l}6.5 \\
- \\
-\end{array}$ & $\begin{array}{l}96 \cdot 6 \\
92 \cdot 8 \\
84 \cdot 5 \\
95 \cdot 7\end{array}$ & $\begin{array}{l}37 \\
33 \\
30 \\
33\end{array}$ & $\begin{array}{l}94 \\
82 \\
84 \\
87\end{array}$ & $\begin{array}{r}\overline{8} \\
12 \\
\end{array}$ & 25 \\
\hline $41 / 57$ & $\begin{array}{l}\text { B } \\
\text { D } \\
\text { D } \\
\text { A }\end{array}$ & $\begin{array}{l}70 \\
84 \\
85 \\
78\end{array}$ & $\begin{array}{l}0.212 \\
0.225 \\
0.211 \\
0.217\end{array}$ & $\begin{array}{l}56 \\
52 \\
56 \\
60 \\
\end{array}$ & $\begin{array}{l}3 \cdot 8 \\
4 \cdot 3 \\
3 \cdot 8 \\
3 \cdot 6\end{array}$ & $\begin{array}{l}95 \cdot 0 \\
91 \cdot 5 \\
90 \cdot 4 \\
96 \cdot 4\end{array}$ & $\begin{array}{l}41 \\
34 \\
39 \\
41\end{array}$ & $\begin{array}{l}101 \\
107 \\
110 \\
108\end{array}$ & $\begin{array}{l}\overline{4 \cdot 5} \\
6 \cdot 5 \\
- \\
\end{array}$ & 22 \\
\hline $42 / 57$ & $\begin{array}{l}\text { B } \\
\text { D } \\
\text { A }\end{array}$ & $\begin{array}{r}76 \\
110 \\
76 \\
\end{array}$ & $\begin{array}{l}0.235 \\
0.233 \\
0.228 \\
\end{array}$ & $\begin{array}{l}46 \\
38 \\
49 \\
\end{array}$ & $\begin{array}{l}5.1 \\
6 \cdot 1 \\
4 \cdot 7 \\
\end{array}$ & $\begin{array}{l}95.1 \\
76.9 \\
95.9 \\
\end{array}$ & $\begin{array}{l}21 \\
22 \\
31 \\
\end{array}$ & $\begin{array}{r}98 \\
101 \\
110 \\
\end{array}$ & $\overline{4}$ & 15 \\
\hline $46 / 57$ & $\begin{array}{l}\text { B } \\
\text { D } \\
\text { D } \\
\text { A } \\
\end{array}$ & $\begin{array}{l}63 \\
68 \\
74 \\
68 \\
\end{array}$ & $\begin{array}{l}0 \cdot 197 \\
\overline{0.205} \\
0 \cdot 198\end{array}$ & $\begin{array}{l}\frac{37}{36} \\
42\end{array}$ & $\begin{array}{l}5 \cdot 3 \\
5 \cdot 7 \\
4 \cdot 7\end{array}$ & $\begin{array}{l}98 \cdot 5 \\
93 \cdot 7 \\
89 \cdot 8 \\
99 \cdot 8\end{array}$ & $\begin{array}{l}16 \\
18 \\
20 \\
18\end{array}$ & $\begin{array}{r}104 \\
105 \\
95 \\
94\end{array}$ & $\begin{array}{l}\overline{3.5} \\
6.5 \\
-\end{array}$ & 12 \\
\hline $47 / 57$ & $\begin{array}{l}\text { B } \\
\text { D }\end{array}$ & $\begin{array}{l}70 \\
72\end{array}$ & $\begin{array}{l}0.235 \\
0.225\end{array}$ & $\begin{array}{l}49 \\
52\end{array}$ & $\begin{array}{l}4 \cdot 8 \\
4 \cdot 3\end{array}$ & $\begin{array}{l}96 \cdot 9 \\
95 \cdot 0\end{array}$ & $\begin{array}{l}29 \\
21\end{array}$ & $\begin{array}{l}118 \\
108\end{array}$ & $\overline{4 \cdot 5}$ & 11 \\
\hline $50 / 57$ & $\begin{array}{l}\mathbf{B} \\
\mathbf{D}\end{array}$ & $\begin{array}{l}70 \\
83\end{array}$ & $\begin{array}{l}0 \cdot 199 \\
0 \cdot 214\end{array}$ & $\begin{array}{l}45 \\
41\end{array}$ & $\begin{array}{l}4 \cdot 4 \\
5 \cdot 2\end{array}$ & $\begin{array}{l}97 \cdot 0 \\
95 \cdot 9\end{array}$ & $\begin{array}{l}24 \\
22\end{array}$ & $\begin{array}{l}93 \\
83\end{array}$ & $\overline{2 \cdot 5}$ & 22 \\
\hline $56 / 57$ & $\begin{array}{l}\text { B } \\
\text { D }\end{array}$ & $\begin{array}{l}78 \\
70\end{array}$ & $\begin{array}{l}0.230 \\
0.244\end{array}$ & $\begin{array}{l}51 \\
48\end{array}$ & $\begin{array}{l}4 \cdot 5 \\
5 \cdot 1\end{array}$ & $\begin{array}{l}94 \cdot 6 \\
92 \cdot 0\end{array}$ & $\begin{array}{l}23 \\
14\end{array}$ & $\begin{array}{l}84 \\
87\end{array}$ & $\overline{3 \cdot 2}$ & 14 \\
\hline $58 / 57$ & $\begin{array}{l}\text { B } \\
\text { D }\end{array}$ & $\begin{array}{l}85 \\
84\end{array}$ & $\begin{array}{l}0 \cdot 285 \\
0.295\end{array}$ & $\begin{array}{l}50 \\
46\end{array}$ & $\begin{array}{l}5 \cdot 7 \\
6 \cdot 4\end{array}$ & $\begin{array}{l}97 \cdot 1 \\
93 \cdot 4\end{array}$ & $\begin{array}{l}45 \\
31\end{array}$ & $\begin{array}{l}95 \\
84\end{array}$ & $\overline{8 \cdot 0}$ & $\begin{array}{l}27 \\
24\end{array}$ \\
\hline Mean & $\begin{array}{l}\text { B } \\
\text { D }\end{array}$ & $\begin{array}{l}82 \\
86\end{array}$ & $\begin{array}{l}0.239 \\
0.232 \dagger\end{array}$ & $\begin{array}{l}52 \\
48\end{array}$ & $\begin{array}{l}4 \cdot 8 \\
4 \cdot 8 \dagger\end{array}$ & $\begin{array}{l}96 \cdot 7 \\
90 \cdot 7\end{array}$ & $\begin{array}{l}34 \cdot 5 \\
27 \cdot 5\end{array}$ & $\begin{array}{r}103 \\
99\end{array}$ & $\overline{7 \cdot 4}$ & 18 \\
\hline $\begin{array}{l}P \text { values } \\
\text { for diff. }\end{array}$ & B-D & $>0.05$ & $>0.05$ & $>0.05$ & $>0.05$ & 0.001 & 0.05 & $>0.05$ & & \\
\hline
\end{tabular}

$\mathrm{V}_{\mathrm{O}_{2}}=$ Oxygen uptake STPD

$\mathrm{A}-\mathrm{V}_{\mathrm{O}_{2}}=$ Arterio-venous oxygen difference

$\mathrm{CO}=$ Cardiac output

$\mathrm{SaO}_{2}=$ Arterial oxygen saturation
$\overline{\mathrm{P}}_{\mathrm{PA}}=$ Mean pulmonary artery pressure

$\overline{\mathbf{P}}_{\mathrm{BA}}=$ Mean brachial artery pressure

$\mathrm{PCV}=$ Pulmonary capillary venous pressure

$\mathrm{B}=$ Before

$\mathbf{D}=$ During

A $=$ After acetylcholine infusion
* = Values representing the highest dose of acetylcholine with complete hæmodynamic study $\dagger=$ Only 9 observations

Table IV gives the result from three patients where the carbon dioxide partial pressure was determined in the arterial blood under the same circumstances. There was usually a slight decrease in the carbon dioxide partial pressure when acetylcholine was infused.

The data presented in Tables II-IV indicate a more pronounced effect of acetylcholine during light work than at rest. However, there is no difference as to the trends in the various components investigated and the discussion will be limited to the effects during exercise. The immediate response to acetylcholine is shown in Fig. 1. The delay observed is mainly due to incomplete filling 
TABLE III

Respiratory and Cardiac Data, during Exercise, before and during a Constant Infusion of ACETylCholine

\begin{tabular}{|c|c|c|c|c|c|c|c|c|c|}
\hline Case No. & & Heart rate & $\mathrm{V}_{\mathrm{O}_{2}}$ & $\mathrm{~A}-\mathrm{V}_{\mathrm{O}_{2}}$ & $\mathrm{CO}$ & $\mathrm{Sa}_{2}$ & $\overline{\mathrm{P}}_{\mathrm{PA}}$ & $\overline{\mathrm{P}}_{\mathrm{BA}}$ & A. chol. dose \\
\hline $18 / 57$ & $\begin{array}{l}\mathrm{B} \\
\mathrm{D}\end{array}$ & $\begin{array}{l}150 \\
152\end{array}$ & $\begin{array}{l}0.530 \\
0.539\end{array}$ & $\begin{array}{l}144 \\
119\end{array}$ & $\begin{array}{l}3 \cdot 7 \\
4 \cdot 5\end{array}$ & $\begin{array}{l}99 \cdot 2 \\
93 \cdot 0\end{array}$ & $\begin{array}{l}86 \\
63\end{array}$ & $\begin{array}{l}86 \\
83\end{array}$ & $14 \cdot 5$ \\
\hline $20 / 57$ & $\begin{array}{l}\mathrm{B} \\
\mathrm{D}\end{array}$ & $\begin{array}{l}160 \\
142\end{array}$ & $\begin{array}{l}0.705 \\
0.586\end{array}$ & $\begin{array}{l}117 \\
107\end{array}$ & $\begin{array}{l}6 \cdot 0 \\
5 \cdot 5\end{array}$ & $\begin{array}{l}96 \cdot 9 \\
96 \cdot 1\end{array}$ & $\begin{array}{l}42 \\
29\end{array}$ & $\begin{array}{l}126 \\
127\end{array}$ & $14 \cdot 0$ \\
\hline $37 / 57$ & $\begin{array}{l}\mathrm{B} \\
\mathrm{D}\end{array}$ & $\begin{array}{l}100 \\
100\end{array}$ & $\begin{array}{l}0 \cdot 704 \\
0 \cdot 703\end{array}$ & $\begin{array}{l}78 \\
73\end{array}$ & $\begin{array}{l}9 \cdot 0 \\
9 \cdot 6\end{array}$ & $\begin{array}{l}95 \cdot 2 \\
88 \cdot 7\end{array}$ & $\begin{array}{l}49 \\
37\end{array}$ & $\begin{array}{r}103 \\
95\end{array}$ & $6 \cdot 0$ \\
\hline $41 / 57$ & $\begin{array}{l}\mathrm{B} \\
\mathrm{D}\end{array}$ & $\begin{array}{l}128 \\
132\end{array}$ & $\begin{array}{l}0.459 \\
0.417\end{array}$ & $\begin{array}{r}112 \\
91\end{array}$ & $\begin{array}{l}4 \cdot 1 \\
4 \cdot 6\end{array}$ & $\begin{array}{l}96 \cdot 6 \\
88 \cdot 7\end{array}$ & $\begin{array}{l}63 \\
52\end{array}$ & $\begin{array}{l}113 \\
105\end{array}$ & $3 \cdot 5$ \\
\hline $42 / 57$ & $\begin{array}{l}\mathrm{B} \\
\mathrm{D}\end{array}$ & $\begin{array}{l}116 \\
140\end{array}$ & $\begin{array}{l}0.555 \\
0 \cdot 515\end{array}$ & $\begin{array}{l}79 \\
64\end{array}$ & $\begin{array}{l}7 \cdot 0 \\
8 \cdot 0\end{array}$ & $\begin{array}{l}94 \cdot 8 \\
80 \cdot 4\end{array}$ & $\begin{array}{l}49 \\
32\end{array}$ & $\begin{array}{l}115 \\
117\end{array}$ & $3 \cdot 5$ \\
\hline $46 / 57$ & $\begin{array}{l}\text { B } \\
\text { D }\end{array}$ & $\begin{array}{l}112 \\
121\end{array}$ & $\begin{array}{l}0.547 \\
0.703\end{array}$ & $\begin{array}{l}88 \\
94\end{array}$ & $\begin{array}{l}6 \cdot 2 \\
7 \cdot 5\end{array}$ & $\begin{array}{l}99 \cdot 0 \\
97 \cdot 6\end{array}$ & $\begin{array}{l}43 \\
32\end{array}$ & $\begin{array}{l}123 \\
112\end{array}$ & $3 \cdot 5$ \\
\hline $47 / 57$ & $\begin{array}{l}\text { B } \\
\text { D }\end{array}$ & $\begin{array}{r}86 \\
106\end{array}$ & $\begin{array}{l}0.414 \\
0.573\end{array}$ & $\begin{array}{l}93 \\
93\end{array}$ & $\begin{array}{l}4 \cdot 5 \\
6 \cdot 2\end{array}$ & $\begin{array}{l}96 \cdot 4 \\
94 \cdot 4\end{array}$ & $\begin{array}{l}46 \\
36\end{array}$ & $\begin{array}{l}120 \\
121\end{array}$ & $4 \cdot 5$ \\
\hline $50 / 57$ & $\begin{array}{l}\mathrm{B} \\
\mathrm{D}\end{array}$ & $\begin{array}{l}72 \\
80\end{array}$ & $\begin{array}{l}0 \cdot 396 \\
0 \cdot 396\end{array}$ & $\begin{array}{c}67 \\
67\end{array}$ & $\begin{array}{l}5 \cdot 9 \\
5 \cdot 9\end{array}$ & $\begin{array}{l}97 \cdot 1 \\
95 \cdot 3\end{array}$ & $\begin{array}{l}38 \\
33\end{array}$ & $\begin{array}{l}103 \\
106\end{array}$ & $2 \cdot 5$ \\
\hline $56 / 57$ & $\begin{array}{l}\text { B } \\
\text { D }\end{array}$ & $\begin{array}{l}110 \\
110\end{array}$ & $\begin{array}{l}0 \cdot 764 \\
0 \cdot 760\end{array}$ & $\begin{array}{r}96 \\
103\end{array}$ & $\begin{array}{l}8 \cdot 0 \\
7 \cdot 4\end{array}$ & $\begin{array}{l}95 \cdot 5 \\
93 \cdot 1\end{array}$ & $\begin{array}{l}48 \\
42\end{array}$ & $\begin{array}{r}100 \\
97\end{array}$ & $4 \cdot 5$ \\
\hline $58 / 57$ & $\begin{array}{l}\text { B } \\
\text { D }\end{array}$ & $\begin{array}{l}124 \\
115\end{array}$ & $\begin{array}{l}0 \cdot 573 \\
0.561\end{array}$ & $\begin{array}{c}80 \\
68\end{array}$ & $\begin{array}{l}7 \cdot 2 \\
8 \cdot 3\end{array}$ & $\begin{array}{l}98 \cdot 1 \\
86 \cdot 0\end{array}$ & $\begin{array}{l}67 \\
52\end{array}$ & $\begin{array}{r}96 \\
115\end{array}$ & $8 \cdot 0$ \\
\hline Mean & $\begin{array}{l}\text { B } \\
\text { D }\end{array}$ & $\begin{array}{l}116 \\
120\end{array}$ & $\begin{array}{l}0.565 \\
0.575\end{array}$ & $\begin{array}{l}95 \\
88\end{array}$ & $\begin{array}{l}6 \cdot 2 \\
6 \cdot 8\end{array}$ & $\begin{array}{l}96 \cdot 9 \\
91 \cdot 3\end{array}$ & $\begin{array}{l}53 \\
41\end{array}$ & $\begin{array}{l}110 \\
108\end{array}$ & \\
\hline $\begin{array}{l}\text { P values } \\
\text { for diff. }\end{array}$ & B-D & $>0.05$ & $>0.05$ & $>0.05$ & 0.01 & 0.001 & 0.001 & $>0.05$ & \\
\hline
\end{tabular}

$\mathrm{V}_{\mathrm{O}_{2}}=$ Oxygen uptake STPD

$\overline{\mathbf{P}}_{\mathrm{PA}}=$ Mean pulmonary artery pressure

$\mathrm{B}=$ Before

$\mathrm{A}-\mathrm{V}_{\mathrm{O}_{2}}=$ Arterio-venous oxygen difference $\overline{\mathrm{P}}_{\mathrm{BA}}=$ Mean brachial artery pressure

$\mathrm{D}=$ During

$\mathrm{CO}=$ Cardiac output

$\mathrm{SaO}_{2}=$ Arterial oxygen saturation

$\mathrm{PCV}=$ Pulmonary capillary venous pressure $\mathrm{A}=$ After acetylcholine infusion

of the catheter with acetylcholine solution at the start. In those eight cases where continuous records were taken during the first minutes of acetylcholine infusion, the values representing the 1 st and 5th minutes of infusion were chosen to illustrate the immediate response to acetylcholine. These data are presented as means in Fig. 2.

The pressure in the pulmonary artery shows a highly significant decrease during acetylcholine infusion. This pressure decrease is out of proportion to the very slight decrease in pulmonary capillary venous pressure found in Cases 4 and 6/58. These findings correspond closely to those reported by Fritts et al. (1958) in normal subjects during hypoxia.

Both at rest and work the cardiac output tends to increase during acetylcholine infusion. This tendency is barely significant at rest but during work would occur by chance less often than 1 in 100 times. At the same time the arterio-venous oxygen difference tends to decrease but this change is not statistically significant $(\mathrm{p}>0 \cdot 05)$.

Heart rate is apparently not affected by acetylcholine infusion $(p>0.05$ both at rest and during work). However, in those cases where the oxygen saturation decreased to below 85 per cent, the heart rate increased but the observations were too few to be significant. 
TABLE IV

Respiratory and Circulatory Data in 3 Patients with Mitral Stenosis at Rest, during Exercise, before and DURING THE INFUSION OF ACETYLCHOLINE

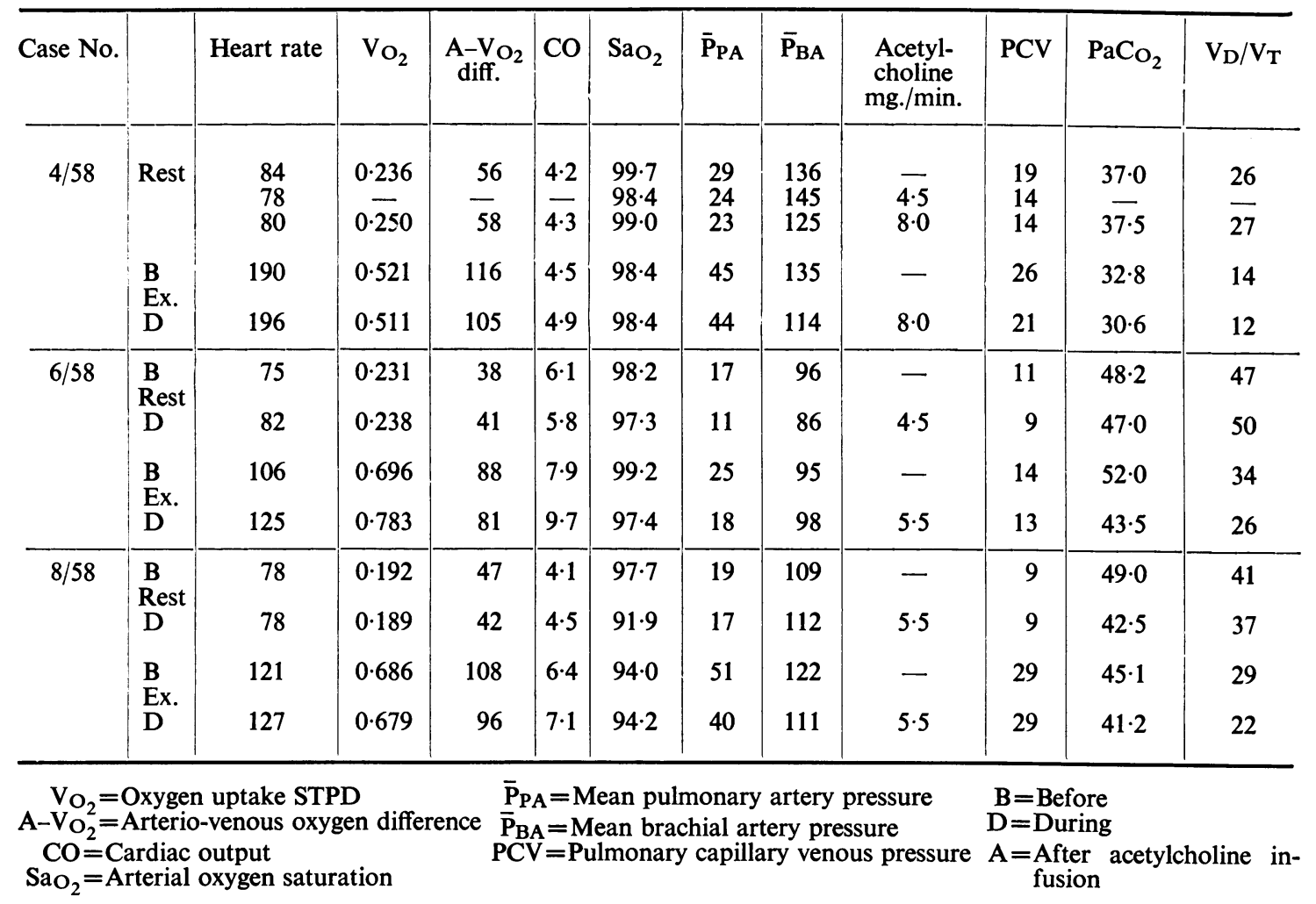

The effect on the pulmonary ventilation and arterial oxygen saturation contrast with each other. Though the ventilation increases slightly $(p=0.05-0.01)$ at a constant oxygen consumption, the arterial oxygen saturation decreased markedly $(\mathrm{p}=0 \cdot 001)$. The data in Table IV indicate rather a hyperventilation as shown by the ratio of the dead space ventilation to total ventilation.

These data can be compared to the results during hypoxia and room air breathing reported by Fritts et al. (1958). In their cases no change in pulmonary ventilation could be observed, but during hypoxia there was an increased desaturation of the arterial blood.

\section{Discussion}

Infusion of acetylcholine in the pulmonary artery of patients with mitral stenosis caused a decrease of pulmonary arterial pressures both at rest and during exercise. The present study thus confirms the findings of Harris and of Wood et al. that the pulmonary arterial blood pressure can be lowered by acetylcholine in certain cases. In our cases, however, the effect was equally well demonstrated in patients with an almost normal pulmonary artery pressure at rest, when the investigation was repeated during light exercise. Thus there seems to be no fundamental difference as regards the action of acetylcholine between cases with a high or normal pulmonary artery pressure as postulated by Harris. We could further demonstrate that the cardiac output usually increased, when it was measured under steady state conditions, thus confirming a decrease in pulmonary vascular resistance after acetylcholine. It is, however, impossible from our data, as well as from those of Wood or Harris, to know if this decrease is due to counteraction of the drug against the mechanism that increases the pressure during the evolution of the disease. 


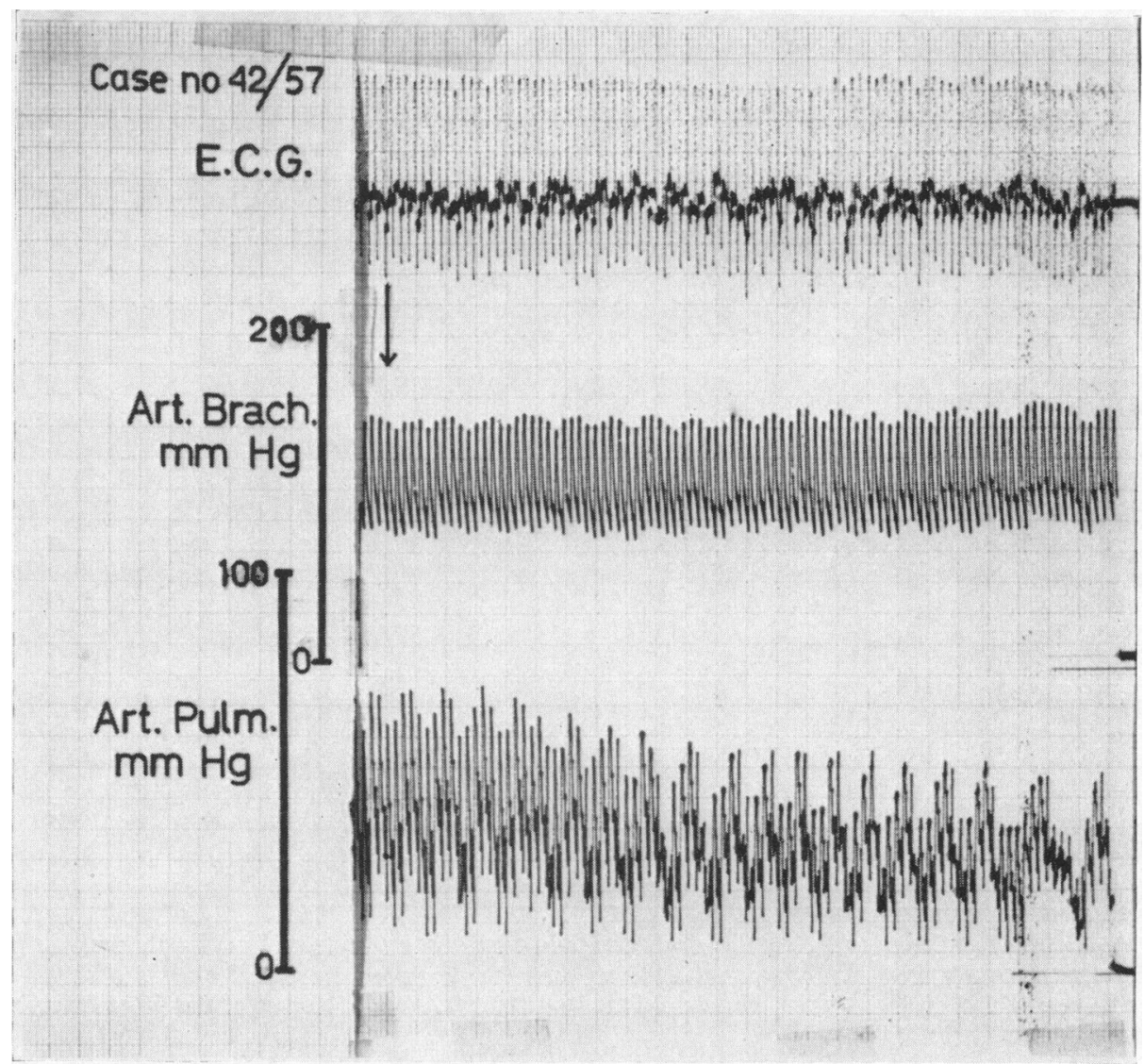

FIG. 1.-Blood pressure in the brachial and pulmonary artery in Case No. 42/57 recorded with lead II when the infusion of $3.5 \mathrm{mg}$. acetylcholine $/ \mathrm{min}$. starts.

The increase of pulmonary arterial pressure and of pulmonary vascular resistance during exercise in patients with mitral stenosis, which has been demonstrated by several authors, has sometimes been thought to be due to increased vascular tone. In the present study this increase in pressures could be counteracted to a certain degree by the administration of acetylcholine. There was, however, never complete suppression of pressure rise during these conditions. The increase in pressure in the pulmonary artery during exercise, remaining during the infusion of acetylcholine, may be due partly to the increased heart rate causing a decrease in the filling time of the left ventricle, i.e. a passive pulmonary hypertension and partly to a constriction of the pulmonary vascular bed. The degree of each component cannot be quantitatively estimated at present.

There are in the present study findings to indicate that the action of acetylcholine is not solely a counteraction against an active increase in vascular tone of the pulmonary circuit. The demonstration that acetylcholine gave a rapid decrease of the arterial oxygen saturation, both at rest and during exercise, is a new finding of importance for the evaluation of its action on the lungs. This change in arterial oxygen saturation must be due to a shift in the ventilation-perfusion ratio of the lungs. This could be caused by an increase in dead space ventilation or to increase of intrapulmonary shunts (increased blood flow through poorly ventilated areas). It seems improbable that such a decrease in oxygen saturation as 7 per cent (mean value) could be caused solely by increase in dead space ventilation, especially as the total ventilation was only slightly increased and the ventilation per litre oxygen consumption only showed minor changes. It is furthermore impossible that 
Early effects of Ac.choline during work

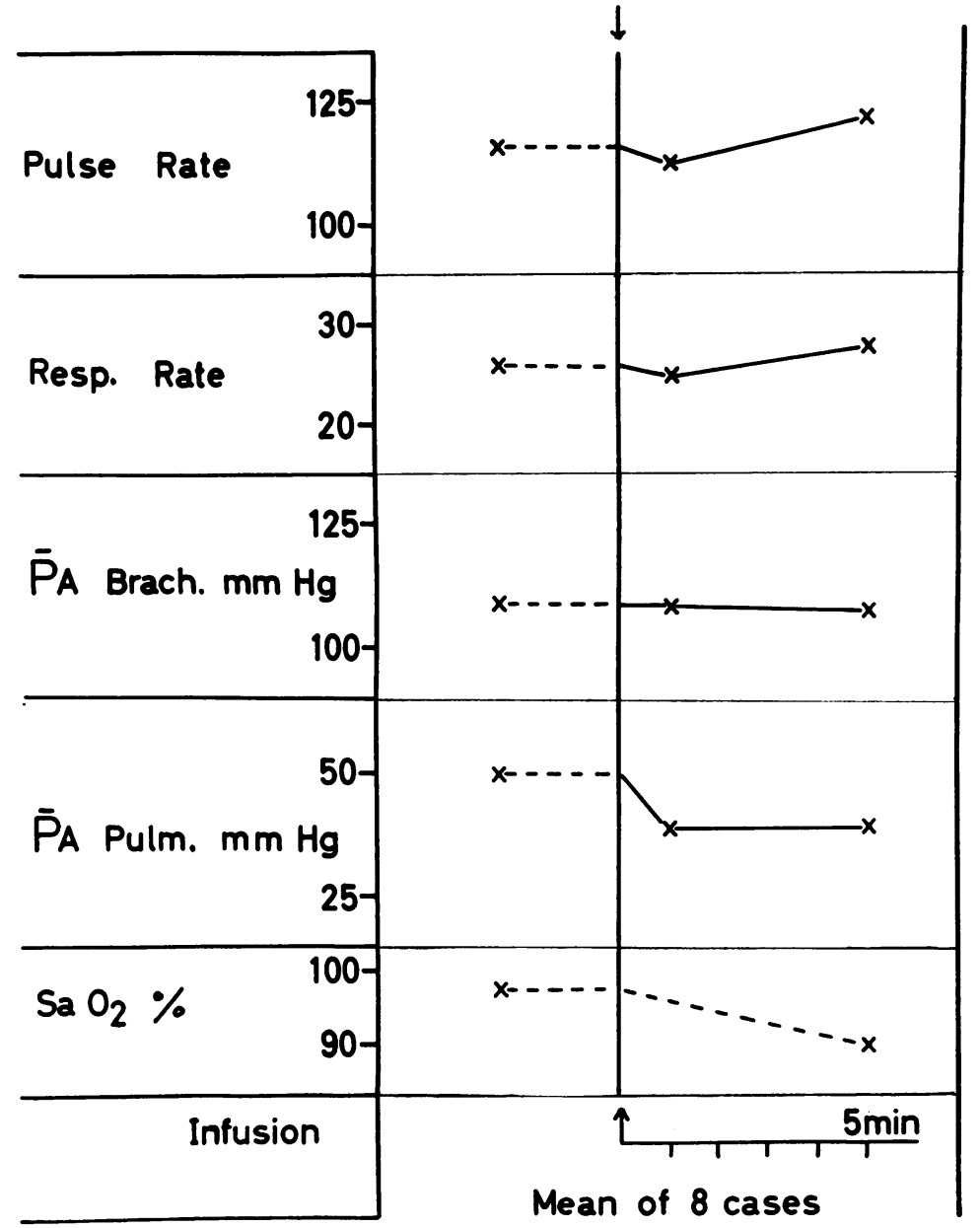

Fig. 2.-Mean exercise values of heart rate, respiratory rate, and blood pressures in the brachial and pulmonary artery before, and after, the first minute and the fifth minute of acetylcholine infusion in eight patients with mitral valvular disease.

the infused acetylcholine could have any action on the bronchial muscles as it was given in such a low dose as not to give any effect on the systemic circulation. These assumptions were supported by the results in the three cases in which the carbon dioxide partial pressure was determined. In these cases a slight decrease in this pressure was noted during infusion of acetylcholine at the same time as a decrease in the ratio $V_{D} / V_{T}$ was observed. The same effects were noted in the hæmodynamic studies as in the other cases but the effect on oxygen saturation was less evident. However, in Case 6/58 acetylcholine gave a marked decrease in arterial oxygen saturation at rest, with the same findings as in the other two cases regarding ventilation and carbon dioxide pressure.

The most probable action of acetylcholine in these patients seems thus to be an increase in the intrapulmonary shunting of blood. The explanation of this action is probably that in certain parts of the lungs an alveolar hypoventilation exists, and this affects the vascular bed through a hypoxic stimulus causing a functional restriction of it. This situation corresponds to the compensated form of non-uniform ventilation to blood-flow ratios as described by Comroe et al. (1957). When acetylcholine is infused in a steady state, vasodilation occurs and the non-uniform ventilation to blood-flow 
ratio is revealed. At the same time the pulmonary arterial pressure decreases because of the increased area of the vascular bed. The changes found would thus be the result of interference with a definitely established physiological mechanism rather than any influence on a presumed "protective" vasoconstriction.

The decrease of arterial oxygen saturation is not without importance for the circulation. It seems probable that the increase in heart rate and cardiac output observed in some cases might be due to the arterial unsaturation.

\section{SUMMARY AND CONCLUSION}

Acetylcholine was given in the pulmonary artery at a constant rate in a dose of 3 to $14.5 \mathrm{mg}$. $/ \mathrm{min}$. to 13 patients with mitral valvular disease. The cardiac output and pressures in the pulmonary and systemic circuit were determined before the start of infusion and during the infusion. The observations were repeated twice in every patient, the first determinations made at rest and the second when the patient performed a slight exercise (about $100 \mathrm{~kg} . / \mathrm{min}$.) at a steady rate. The two periods were separated by 15 minutes rest, when no acetylcholine was given.

During the infusion of acetylcholine, both at rest and exercise, the cardiac output was higher, and the pulmonary arterial pressure and the arterial oxygen saturation lower than at the control observations. These differences were significant statistically. There was no significant difference regarding heart rate, oxygen consumption, or brachial arterial pressure.

These findings can be explained as due to the interference by acetylcholine with an adjustment of the pulmonary vascular bed to a hypoxic stimulus caused by an alveolar hypoventilation in some parts of the lungs. No observations during the present study necessitate the hypothesis of an active pulmonary hypertension to protect the capillaries from an excessive pressure as suggested by various authors.

Further studies are indicated in order to clarify the mode of action of acetylcholine on the pulmonary circulation in patients with heart disease.

\section{REFERENCES}

Comroe, J. H., Forster, R. E., DuBois, A. B., Briscoe, W. A., and Carlsen, E. (1957). The Lung. The Yearbook Publishers Inc., Chicago.

Fritts, H. W., Harris, P., Clauss, R. H., Odell, J. E., and Cournand, A. (1958). J. clin. Invest., $37,99$.

Harris, P. (1957). Brit. Heart J., 19, 272.

, Fritts, H. W., Clauss, R. H., Odell, J. E., and Cournand, A. (1956). Proc. Soc. exper. Biol. Med., $93,77$.

Wood, P., Besterman, E. M., Towers, M. K., and McIlroy, M. B. (1957). Brit. Heart J., $19,179$. 